\title{
28. NICKEL PORPHYRINS FROM DEEP SEA DRILLING PROJECT SITES 415 AND 416
}

\author{
Susan E. Palmer, Department of Geology, and Earl W. Baker, Department of Chemistry, Florida Atlantic \\ University, Boca Raton, Florida
}

\section{INTRODUCTION}

One Miocene and seven Lower Cretaceous DSDP Leg 50 sediment samples from Sites 415 and 416, drilled in the continental margin off southern Morocco, were studied for tetrapyrrole-pigment content. Two Lower Cretaceous samples from adjacent Site 370, drilled during Leg 41 , were analyzed for comparison; however, no useful data resulted.

Hole 416A samples from 1121 to 1362 meters contained low concentrations of nickel porphyrins $(0.01$ to $0.13 \mu \mathrm{g} / \mathrm{g}$ ) in which the etioporphyrin series comprised at least 50 per cent of the total mixture. These observations and the absence of early to intermediate products of chlorophyll diagenesis (chlorins and free-base porphyrins) suggest an advanced stage in diagenesis. The absence of vanadyl porphyrins, previously found in deeply buried or thermally altered sediments off the west coast of Africa during Legs 40 and 41 , should also be noted (Baker et al., 1978a,b).

The nickel-porphyrin fractions from the Hole 416A samples and those from Leg 40 and 41 Cretaceous samples are all similar, since they are composed only of porphyrins of the DPEP and etio series, and the oddmolecular-weight metalloporphyrins are absent. Oddmolecular-weight metalloporphyrins were found in Cretaceous samples from other northern Atlantic sites (Legs 38, 43, 44, 47, and 48) and may represent either different source material or different diagenetic histories.

\section{ANALYTICAL METHODS}

Core samples were stored frozen until the time of analysis. One hundred grams (wet weight) of sediment were extracted with acetone:methanol $(9: 1)$ in a ball mill until devoid of pigment. Nickel porphyrins were isolated from the crude extracts by chromatography over Alumina Grade III with 1:1 cyclohexane:benzene and further purified by liquid-liquid extraction using methylsulfoxide:heptane. The electronic spectra were recorded using a Perkin-Elmer Model 575 scanning spectrophotometer. Ratios of the $\alpha(554 \mathrm{~nm})$ to $\beta(515 \mathrm{~nm})$ visible-wavelength band intensities were computed for each nickel-porphyrin fraction.

Mass-spectrometric analyses of nickel porphyrins were made by solid-probe injection using a DuPont 491-BR mass spectrometer. For samples from Cores 18, 23 , and 28 of Hole $416 \mathrm{~A}$, source and probe temperatures were 265 to $275^{\circ} \mathrm{C}$ and 280 to $300^{\circ} \mathrm{C}$, respectively. Higher temperatures $\left(\right.$ source $=290^{\circ} \mathrm{C}$, probe $=310^{\circ} \mathrm{C}$ ) were required to volatilize porphyrins in the sample from Core 416A-14. The spectral peak intensities were normalized for the DPEP and etio series and the DPEPto-etio ratio was computed for each sample. The purified pigment fraction from Core 416A-9 was too small for mass-spectrometric analysis.

\section{RESULTS AND DISCUSSION}

The electronic spectrometric data and core descriptions for the two samples from Leg 41 and eight from Leg 50 are given in Table 1. Pigments were not detected in samples from Cores 370-39, 415-4, 416A-42, and 416A-48; only nickel porphyrins were present in the remaining five samples from Hole 416A. The concentrations are low $(0.01$ to $0.13 \mu \mathrm{g} / \mathrm{g})$ in comparison with nickel-porphyrin fractions from Leg 40 and 41 samples, in which pigment yields one or two orders of magnitude greater were found. The organic carbon content of these sediments is also low relative to Leg 40 and 41 samples (Baker et al., 1978a,b).

Ratios of the $\alpha(554 \mathrm{~nm})$ to $\beta(515 \mathrm{~nm})$ band intensities of the nickel-porphyrin fractions ranged from 2.3 to 2.5 , with no apparent trend (Table 1). Since synthetic nickel DPEP has an $\alpha / \beta$ ratio of approximately 2.0 and the ratio for nickel etioporphyrin is 3.0 , a value of 2.3 to 2.5 would indicate a 2 to 1 or 1 to 1 mixture of the two porphyrins. Thus, in initial evaluation of the data, it appeared that porphyrins of the etio series contributed 30 to 50 per cent of the total fraction. Likewise, the absence of spectral bands at 520 and $560 \mathrm{~nm}$ indicated that metailoporphyrins having odd molecular weights were not present.

Mass-spectrometric analyses show that these first approximations were fairly accurate for samples from Cores 416A-23 and 416A-28, but not for Cores 416A-14 and 416A-18. In Table 2, the DPEP-to-etio ratio for samples from Cores $416 \mathrm{~A}-23$ and $416 \mathrm{~A}-28$ is approximately 1.0 , while a 4.4 and 0.4 ratio resulted for samples from Cores 416A-14 and 416A-18, respectively. Apparently, the visible-band ratios reflect the unique complexities of the porphyrin fraction. In this case, the DPEP-to-etio ratios are better approximated through mass-spectrometric analyses. For example, in Core $416 \mathrm{~A}-14$, the DPEP/etio ratio is 4.4 but the $\alpha / \beta$ ratio is 2.4. The fact that both $\mathrm{C}_{32}$ and the $\mathrm{C}_{30}$ DPEP porphyrins are major components could explain why the $\alpha / \beta$ ratio is not closer to 2.0 . For comparison, nickel desmethyl DPEP, a $C_{31}$ porphyrin, has a peak ratio of 2.3 (Milton et al., 1978). The predominance of the $\mathrm{C}_{32}$ and $\mathrm{C}_{30}$ components of the DPEP series was 
TABLE 1

Pigment Data, Sites 370, 415, 416

\begin{tabular}{|c|c|c|c|c|c|c|c|c|c|c|}
\hline Section & Geologic Age ${ }^{a}$ & $\begin{array}{c}\text { Lithologic } \\
\text { Description }\end{array}$ & $\begin{array}{l}\text { Sub-Bottom } \\
\text { Depth } \\
\text { (m) }\end{array}$ & $\begin{array}{c}\text { Organic } \\
\text { Carbon }{ }^{a} \\
(\% \text { by wt.) }\end{array}$ & $\begin{array}{l}\text { Individual } \\
\text { Yield } b \\
(\mu \mathrm{g} / \mathrm{g})\end{array}$ & \multicolumn{4}{|c|}{$\begin{array}{l}\text { UV-Visible Absorption Data } \\
\qquad(\mathrm{nm})\end{array}$} & Pigment Type \\
\hline & & & & & & Soret & $\beta$ & $\alpha$ & $\alpha / \beta$ ratio & \\
\hline $370-27-2$ & Early Albian & Slightly calc. dark-gray mud & 760 & 0.08 & $\sim 0.001$ & 397 & & $(555)$ & & Metalloporphyrin \\
\hline $370-39-3$ & Hauterivian & Calc. dark-gray mud & 950 & 0.31 & No pigment & & & & & \\
\hline $415-4-2$ & Middle Miocene & Calc. greenish-gray mud & 210 & 0.1 & No pigment & & & & & \\
\hline $416 \mathrm{~A}-9-2$ & Hauterivian & Calc. greenish-gray shale & 1121 & 0.4 & 0.02 & 396 & 515 & 554 & $(2.5)$ & Nickel porphyrin \\
\hline $416 \mathrm{~A}-14-4$ & Valanginian & Calc. dark-gray shale & 1227 & 0.06 & 0.01 & 396 & 515 & 554 & $(2.4)$ & Nickel porphyrin \\
\hline $416 \mathrm{~A}-18-3$ & " & Calc. dark-gray shale & 1266 & 0.55 & 0.10 & 395 & 516 & 553 & $(2.3)$ & Nickel porphyrin \\
\hline $416 \mathrm{~A}-23-3$ & $"$ & Calc. dark-gray shale & 1313 & 0.97 & 0.09 & 396 & 515 & 554 & $(2,4)$ & Nickel porphyrin \\
\hline $416 A-28-4$ & $n$ & Calc. dark-gray shale & 1362 & 0.12 & 0.13 & 396 & 515 & 554 & $(2.3)$ & Nickel porphyrin \\
\hline $416 \mathrm{~A}-42-2$ & $"$ & Calc. red-brown shale & 1475 & 0.08 & No pigment & & & & & \\
\hline $416 A-48-2$ & $"$ & Calc, red-brown shale & 1532 & 0.12 & No pigment & & & & & \\
\hline
\end{tabular}

aData obtained from unpublished Leg 50 shipboard summary.

bIndividual pigment yields for nickel porphyrins calculated using the following molar extinction coefficient: $34.820 \mathrm{at} 550 \mathrm{~nm}$.

TABLE 2

Mass-Spectrometric Data on Nickel Porphyrins From Hole 416A

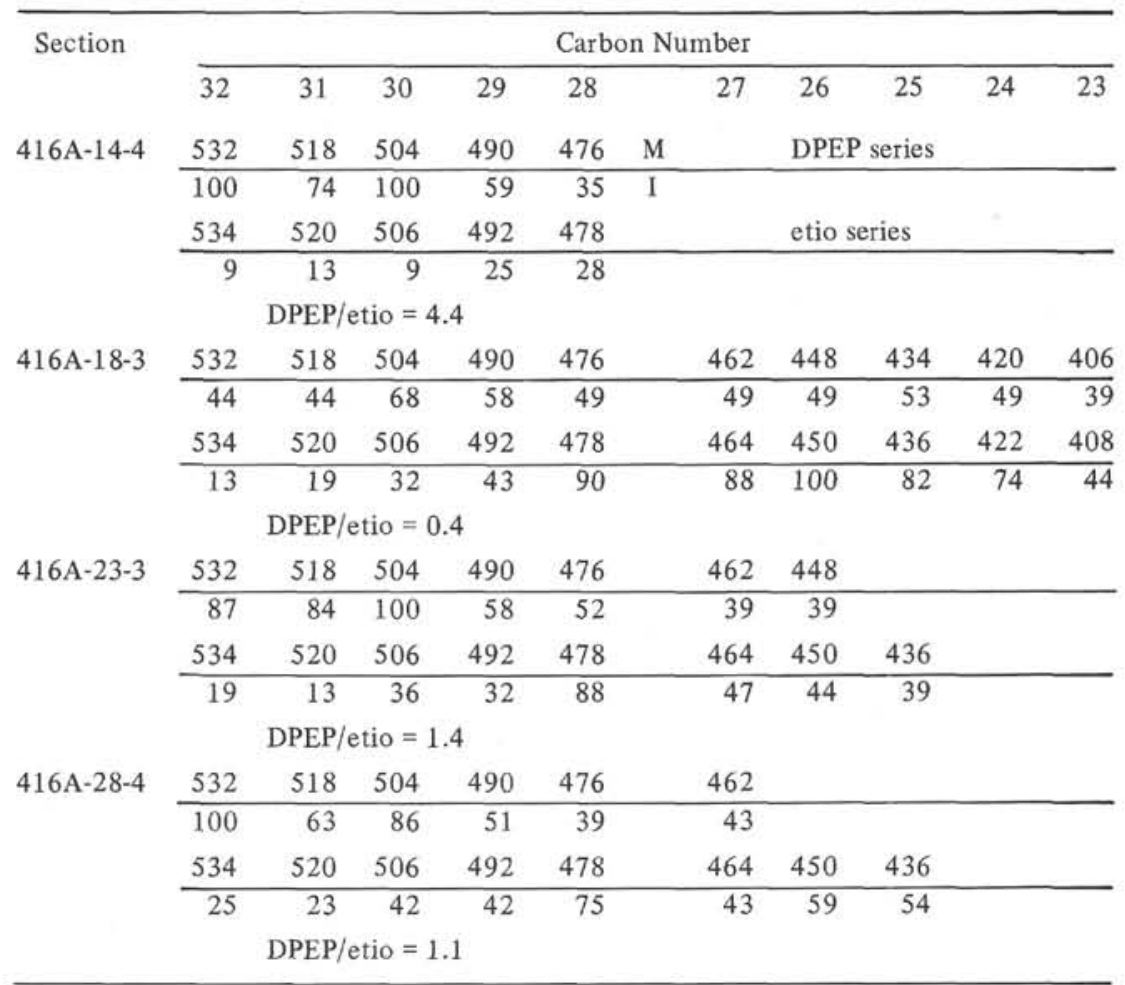

Note: The peak heights (I) for the nickel porphyrins of the etio series have been corrected for the $60 \mathrm{Ni}$ contribution for the corresponding DPEP series. The peak intensities are normalized to 100 for the most intense peak.

observed in a lesser degree in samples from Cores 416A-23 and 416A-28. A similar pattern occurs in the etio series of Core 416A-18; however, in this case, the $\mathrm{C}_{28}$ and $\mathrm{C}_{26}$ components predominate. The massspectrometric analyses of Core 416A-18 show that the etio series makes the major contribution to the mixture; however, 10 members $\left(C_{23}\right.$ to $\left.C_{32}\right)$ are present in each series, in contrast to the more typical six- or sevenmembered series. Perhaps the visible spectrum reflects this wide spread in series components, and, thus, the $\alpha / \beta$ ratio is 2.3 rather than 2.8 or 3.0 , as would be expected for a two-component synthetic mixture of the same DPEP/etio ratio. The influence of the peripheral groups of a particular tetrapyrrole must be kept in mind when the visible peak ratios are used as indicators of the relative abundances of the DPEP to etio series and ultimately as indicators of organic maturity.

The molecular-weight distributions of the nickel porphyrins from samples of Cores 416A-14, 416A-23, and 416A-28 form a trend with increasing depth: the 
DPEP/etio ratio decreases from 4.4 to 1.1 and the spectral envelope increases from 5 members to 7 and 8 members in both the DPEP and etio series (Table 2). In all three cores, the $\mathrm{C}_{32}$ to $\mathrm{C}_{30}$ members of the DPEP series predominate. In contrast, the nickel-porphyrin fraction from Core 416A-18 does not fit into this sequence. In this case, the DPEP/etio ratio is 0.4 . There are 10 members in both series, and the major peak is a $\mathrm{C}_{26}$ porphyrin of the etio series. This sample has a molecular-weight distribution similar to that for Leg 43 samples (Cores 386-60 and 386-63) from Albian-Aptian shales at approximately 920 meters depth of burial (Palmer et al., in press). As mentioned for these Leg 43 samples, the symmetrical 10-member molecular-weight distribution observed for the sample from Core 416A-18 is reminiscent of petroporphyrins. However, in contrast with a petroporphyrin, no members with carbon numbers greater than $\mathrm{C}_{32}$ were observed, and a dealkylated series, with major peaks consisting of $\mathrm{C}_{28}$ to $\mathrm{C}_{25}$ etioporphyrins, was observed.

Analysis of 20 samples shows that the DPEP/etio ratio for a petroporphyrin can range from 0 to 5.8 , with an average value of 1.8. Molecular-weight distributions can contain from 5 to 12 members from $\mathrm{C}_{26}$ to $\mathrm{C}_{38}$ in the DPEP and etio series, with major peaks at $\mathrm{C}_{29}$ to $\mathrm{C}_{32}$ (Baker et al., 1967; Baker and Palmer, 1978).

The discordant nature of the nickel porphyrins in Core 416A-18, with respect to the other three samples from Hole 416A, may be attributed to migration of a thermally more altered material into this particular stratum. More extensive sampling would be required to confirm this idea.

Previous studies have shown that chlorophyll diagenesis reaches an intermediate stage, the chlorinporphyrin transition, in which chlorins (perhaps with structures similar to pheophorbide or deoxomesopyropheophorbide) and free-base porphyrins of the DPEP series occur together (for structures of these model compounds Baker et al., 1978c). Subsequent to free-baseporphyrin formation (aromatization), chelation with nickel or vanadyl occurs; however, the cases where vanadyl porphyrins have been found in deep-sea sediments are limited. At a slightly later diagenetic stage, nickel porphyrins of the DPEP series are slowly converted to the etio series with increasing depth of burial, perhaps at temperatures around 25 to $50^{\circ} \mathrm{C}$. With temperatures more typical of catagenesis ( 50 to $175^{\circ} \mathrm{C}$ ), alkyl-group transfer (transalkylation) or dealkylation can occur (Hunt, 1973). Conditions permitting transalkylation lead to petroporphyrin formation. Severe thermal stress results in complete conversion of DPEP to etio, followed by loss of methylene groups and destruction of the tetrapyrrole ring. Perhaps, in the case of Core 416A-18, where both the DPEP and etio series are present, another set of conditions exists that permits dealkylation without total conversion to the etio series. These conditions may be those where the sediment is exposed for a long period to temperature lower than that required for transalkylation.

\section{CONCLUSIONS}

Sediments at 1121 to 1362 meters, deposited in a continental-rise environment during the Early Cretaceous, are in an early stage of thermal alteration (Shipboard Party, Leg 50, 1977). Nickel-porphyrin data support this conclusion. The conversion of the DPEP to etio series is at least half completed in samples from 1265 to 1362 meters.

Visible-band ratios of nickel porphyrins can be used to approximate the relative contributions of the DPEP and etio series. However, strict adherence to electronic spectral data could be misleading, since other structural features, such as number of methylene substituents, may influence band intensities.

\section{ACKNOWLEDGMENTS}

This research was supported by the Oceanography Section of the National Science Foundation, Grants OCE 74-12438 $\mathrm{A} 02$ and OCE 77-07273. The authors thank Mr. Gerard DeMott for his help with sample work-up, and Dr. Karl S. Schorno, Phillips Petroleum Company, for his review of this report.

\section{REFERENCES}

Baker, E. W. and Palmer, S. E., 1978. Geochemistry of porphyrins. In Dolphin, D. (Ed.), The Porphyrins: New York (Academic Press), v. 3, p. 485.

Baker, E. W., Palmer, S. E., and Huang, W. Y., 1978a. Chlorin and porphyrin geochemistry of DSDP Leg 40 sediments. In Bolli, H. M., Ryan, W. B. F., et al., Initial Reports of the Deep Sea Drilling Project, v. 40: Washington (U.S. Government Printing Office), p. 639-648.

1978b. Intermediate and late diagenetic tetrapyrrole pigments, Leg 41: Cape Verde Rise and Basin. In Lancelot, Y. Seibold, E., et al., Initial Reports of the Deep Sea Drilling Project, v. 41: Washington (U.S. Government Printing Office), p. 825-838.

1978c. Early and intermediate chlorophyll diagenesis of Black Sea sediments: Sites 379, 380 and 381. In Ross, D., Neprochnov, Y., et al., Initial Reports of the Deep Sea Drilling Project, v. 42, Part 2: Washington (U.S. Government Printing Office), p. 707-716.

Baker, E. W., Yen, T. F., Dickie, J. P., Rhodes, R. E., and Clark, L. F., 1967. Mass spectrometry of porphyrins II. characterization of petroporphyrins, J. Am. Chem. Soc., v. 89, p. 3631 .

Hunt, J. M., 1973. Organic geochemistry of the marine environment. In Tissot, B. and Bienner, F. (Eds.), Advances in Organic Geochemistry: Paris (Editions Technip), p. 593.

Milton, C., Dwornik, E. J., Barnes, P. A., Finkelman, R. B., Pabst, A., and Palmer, S., 1978. Abelsonite, nickel porphyrin, a new mineral from the Green River Formation, Utah. Am. Mineralogist, v. 63, p. 930-937.

Palmer, S. E., Huang, W. Y., and Baker, E. W., in press. Tetrapyrrole pigments from Bermuda Rise: DSDP Leg 43. In Tucholke, B., Vogt, P., et al., Initial Reports of the Deep Sea Drilling Project, v. 43: Washington (U.S. Government Printing Office).

Shipboard Party-Leg 50, 1977. Documenting early rifting, Geotimes, v. 22, p. 24. 